\title{
Persepsi Pegawai Negeri Sipil \\ Terhadap Penerapan Undang-Undang Nomor 5 Tahun 2014 Tentang Aparatur Sipil Negara (Studi Kasus Aparatur Sipil Negara Di Kantor Kelurahan Temindung Permai Kecamatan Sungai Pinang Kota Samarinda)
}

\author{
Drs. M. Kasim M., M.Si. \\ Dosen Tidak Tetap Ilmu Administrasi Negara FISIP UWGM Samarinda \\ Rusli, S.E., M.Si. \\ Dosen Tetap Ilmu Administrasi Negara FISIP UWGM Samarinda \\ Pamilu Hasibuan \\ Mahasiswa Ilmu Administrasi Negara FISIP UWGM Samarinda
}

\begin{abstract}
Abstrak
Lahirnya Undang-undang Republik Indonesia Nomor 5 Tahun 2014 Tentang Aparatur Sipil Negara, diharapkan mampu memperbaiki manajemen pemerintahan yang berorientasi pada pelayanan publik karena PNS tidak lagi berorientasi melayani atasannya, melainkan masyarakat. Aturan ini menempatkan PNS sebagai sebuah profesi yang bebas dari intervensi politik dan akan menerapkan sistem karier terbuka yang mengutamakan prinsip professionalisme yang memiliki kompetensi, kualifikasi, kinerja, transparansi, objektivitas, serta bebas dari KKN yang berbasis pada manajemen sumber daya manusia dan mengedepankan sistem merit menuju terwujudnya birokrasi pemerintahan yang profesional.

Tujuan dari penelitian ini adalah mengetahui persepsi pegawai negeri sipil terhadap penerapan Undang-Undang Nomor 5 tahun 2014 tentang Aparatur Sipil Negara di kantor Kelurahan Temindung Permai Kecamatan Sungai Pinang Kota Samarinda beserta dampak yang ditimbulkan UU tersebut. Jenis penelitian ini adalah kualitatif deskriptif, dimana pada penelitian bersifat memberikan gambaran tentang keadaan yang sebenarnya yang terjadi di lapangan. Temuan dari hasil penelitian ini bahwa Persepsi Pegawai Negeri Sipil sangat setuju diterapkan sehingga memberikan peningkatan kualitas disiplin, produktivitas, kemampuan, kinerja pegawai dan berdampak baik bagi pegawai yang berdasarkan kompetensi, kualitas dan prestasi kerja pegawai.
\end{abstract}

Kata Kunci : Persepsi, Pegawai Negeri Sipil, Kelurahan Temindung Permai.

\begin{abstract}
The Law of the Republic of Indonesia Number 5 Year 2014 About the State Civil Apparatus, is expected to improve the management of government-oriented public services because civil servants are no longer oriented to serve his superiors, but the community. This rule places civil servants as a profession free from political intervention and will apply an open career system that prioritizes professionalism principles that have the competence, qualification, performance, transparency, objectivity and free of KKN based on human resource management and prioritize merit system The realization of professional government bureaucracy.
\end{abstract}

The purpose of this study is to know the perception of civil servants on the implementation of Law No. 5 of 2014 on State Civil Apparatus in the office of Kelurahan Temindung Permai Sungai Pinang Subdistrict of Samarinda City and the impact of the law.The type of this research is qualitative descriptive, which in the research is giving an idea about the actual situation that happened in the field.The findings of this study indicate that the Civil Servant Perception is very agreeable to be applied in order to improve the quality of discipline, productivity, ability, employee performance and good impact for employees based on the competence, quality and performance of employees.

Keywords: Perception, Civil Servant, Temindung Permai Village. 


\section{Latar Belakang}

Pembenahan dalam sistem administrasi negara merupakan tugas dantanggung jawab pemerintah, pembenahan ini merupakan hal utama agar tugaspokok dan fungsi pemerintahan dapat dilaksanakan dengan baik, terarah dan dapatdipertanggung jawabkan, sesuai mekanisme dan prosedur yang telah ditetapkansehingga sistem pelayanan terhadap masyarakat diharapkan akan semakin baik. Jikahal ini dilakukan dengan baik, sebagaimana telah dituangkan dalam tujuan nasionalbangsa Indonesia sesuai Pembukaan Undang-undang Dasar Republik IndonesiaTahun1945Alenia Ke-IV,sebagai berikut "Kemudian dari pada itu untuk membentuksuatu pemerintah Negara Indonesia yang melindungi segenap bangsa Indonesia danuntuk memajukan kesejahteraan umum,mencerdaskan kehidupan bangsa dan ikutmelaksanakan ketertiban dunia yang berdasarkan kemerdekaan,perdamaian abadi dankeadilan sosial."

Dalam rangka mewujudkan tujuan nasional diperlukan sistem adminstrasiNegara yang baik dan didukung oleh aparatur penyelenggara Negara yang mampubekerjasecara profesional dan proporsional.Berkaitan dengan perubahan Undang-undang No.43 Tahun 1999 Tentang Pokok-Pokok Kepegawaian dan Undang-undang No.5 Tahun 2014 Tentang Aparatur Sipil Negara yang menuntut AparaturSipil Negara bekerja sesuai dengan yang dikehendaki Undang-undang sesuai dengantuntutan masyarakat yang semakin tinggi sesuai dengan perkembangan globalisasi.

yang harus bekerja secara profesionalisme, proporsionalisme, transparansi, akuntabel,responsib, efektif dan efisien. Hasil kerja dari Aparatur Sipil Negara harus dapatdilaporkan ke pemerintah pusat dan bertanggung jawab baik secara kualitas maupunkuantitas kepada publik. Adapun aparatur sipil Negara harus mempunyai kompetensi,moral yang baik, dan mampu melaksanakan tugasnya sesuai dengan target dansasaran yang akan dicapai untuk meningkat kualitas pelayanan yang baik danpembangunan ditanah air. Aparatur sipil Negara dimana dahulu didalamperkembangan di lapangan terjadi pejabat atau pegawai yang harus dilayanimasyarakat akan tetapi di dalam perkembangan globalisasi yang harus berorientasimelayani publik( Public Service), aparatur sipil Negara dalam melaksanakantugasnya harus terbebas dari intervensi golongan ataupun partai politik danmempunyai integritas yang tinggi serta terbebas dari praktek korupsi, kolusi dannepotisme.

Sumber Daya Manusia yang handal dalam melaksanakan tugas sebagaiAparatur Sipil Negara harus mampu melaksanakan perbaikan yang salah satunyaadalah revolusi mental dengan mendasar tuntunan kehidupan beragama secara benar,selalu memiliki komitmen dalam melayani masyarakat sehingga tercipta goodgovernance .Di setiap organisasi akan bisa dicapai melalui kesadaran Aparatur SipilNegara yang mempunyai etos kerja yang baik sudah barang tentu akan menghasilkankinerja yang baik, sehingga akan didapatkan ASN yang professional. Aparatur SipilNegara dalam menjalankan revolusi mental harus membentengi dengan caramewarisi nilai - nilai kepahlawanan kemerdekaan para pendahulu kita ditambahnilai- nilai moral kehidupan beragama yang diamalkan dengan secara benar dankonsisten. Hal ini diharapkan akan dapat memberikan pelayanan yang lebin baikmanakala memiliki semangat kerja, budaya dan etos kerja, serta motivasi yang tinggi.

Petunjuk operasional revolusi mental melalui aspek pendidikan dan pelatihan,merupakan hal yang sangat utama sebagai upaya untuk meningkatkan kualitassumber daya manusia dan sekaligus sebagai proses investasi jangka panjang, bagipeningkatan kinerja aparatur negara dalam menghadapi tantangan internal bangsa danpersaingan global.

Lahirnya Undang-undang Republik Indonesia Nomor 5 Tahun 2014,Tentang Aparatur Sipil Negara, diharapkan mampu memperbaiki manajemenpemerintahan yang berorientasi pada pelayanan publik karena PNS tidak lagiberorientasi melayani atasannya, melainkan masyarakat. Aturan ini menempatkanPNS sebagai sebuah profesi yang bebas dari intervensi politik dan akan menerapkansistem karier terbuka yang mengutamakan prinsip professionalisme yang memilikikompetensi, kualifikasi, kinerja, transparansi, objektivitas, serta bebas dari KKN yangberbasis pada manajemen sumber daya manusia dan mengedepankan sistem meritmenuju terwujudnya birokrasi pemerintahan yang profesional.

Berdasarkan Undang-undang Republik Indonesia Nomor 23 Tahun 2014Tentang Pemerintahan Daerah bab II Pasal 2 "Daerah kabupaten/kota dibagi ataskelurahan dan/atau Desa. "Pembagian 
wilayah tersebut bertujuan untukmeningkatkan kegiatan pemerintahan yang selaras dengan pelaksanaan pembangunannasional yang merata diseluruh wilayah Negara Kesatuan Republik Indonesia.

Pembagian wilayah selalu dibarengi dengan pengangkatan pegawai yang diberikantugas pokok dan fungsi sesuai tujuan yang ingin dicapai. Yang dimaksud denganpegawai, berdasarkan Undang-undang Republik Indonesia Nomor 43 Tahun 1999Tentang Perubahan atas Undang-undang Republik Indonesia Nomor 8 Tahun 1974Tentang Pokok-Pokok Kepegawaian bab I Pasal 1 ayat (1),Pegawai Negara RepublikIndonesia adalah "Setiap warga Negara Republik Indonesiayang telah memenuhisyarat yang ditentukan, diangkat oleh pejabat yang berwenang dan diserahi tugasdalam suatu jabatan negeri atau diserahi tugas negara lainnya, dan digaji berdasarkanperaturan perundangundangan yang berlaku."

Menjadi Pegawai Negeri Sipil, merupakan hal yang didambakan olehmasyarakat Indonesia terutama oleh para pencari kerja, karena dengan menjadipegawai negeri sipil segala kebutuhan hidup akan terasa terjamin walaupun dengangaji yang tidak terlalu besar. Tawaran yang menggiurkan bila menjadi PegawaiNegeri Sipil adalah gaji tiap bulan, tunjangan jabatan, pensiunan terlebih lagi biladitempatkan di departemen atau instansi yangdapat memberikan pendapatantambahan lebih.

Dalam perkembangan pelaksanaan tugas, Pegawai Negeri melaksanakantugas dan tanggung jawab sesuai Undang-undang Republik Indonesia Nomor 43Tahun 1999 Tentang Perubahan atas Undangundang Republik Indonesia Nomor 8Tahun 1974 Tentang Pokok-Pokok Kepegawaian, kemudian terjadi perubahan sistemadministrasi pemerintahan setelah diberlakukannya Undang-Undang RepublikIndonesia Nomor 5 Tahun 2014, Tentang Aparatur Sipil Negara, diharapkan mampumemperbaiki manajemen pemerintahan yang berorientasi pada pelayanan publikkarena Pegawai Negeri Sipil tidak lagi berorientasi melayani atasannya, melainkanmasyarakat. Aturan ini menempatkan Pegawai Negeri Sipil sebagai sebuah profesiyang bebas dari intervensi politik dan akan menerapkan sistem karier terbuka yangmengutamakan prinsip profesionalisme yang memiliki kompetensi, kualifikasi,kinerja, transparansi, objektivitas, serta bebas dari Kolusi Korupsi dan Nepotismeyang berbasis pada manajemen sumber daya manusia dan mengedepankan sistemmerit menuju terwujudnya birokrasi pemerintahan yang professional.

Berkaitan dengan perubahan undang-undang yang menyebabkan perubahandalam sistem administrasi pemerintahan, sehingga menuntut pegawai untuk wajibmelaksanakan tugas sesuai yang dikehendaki Undang-undang, kemungkinan akanmerubah pola pikir, prilaku dan tindakan yang dilakukan. Berkaitan denganpermasalahan ini, peneliti tertarik secara khusus pemerintah kelurahan yangmerupakan ujung tombak atau tumpuan dalam berbagai program kegiatan pemerintahdalam kaitannya sebagai organisasi pemerintahan terendah di Indonesia. Kelurahanadalah pembagian wilayah administratif di Indonesia di bawah kecamatan.Dalamkonteks otonomi daerah di Indonesia, Kelurahan merupakan wilayah kerja Lurahsebagai Perangkat Daerah Kabupaten atau Kota. Berdasarkan Peraturan MenteriDalam Negeri Nomor 31 Tahun 2006 Tentang Pembentukan, Penghapusan, DanPenggabungan Kelurahan bab II Pasal 2 yaitu "Kelurahan dibentuk untukmeningkatkan pelayanan masyarakat, melaksanakan fungsi pemerintahan, danpemberdayaan masyarakat dalam rangka mempercepat terwujudnya kesejahteraan masyarakat."Berdasarkan Peraturan Daerah Kota Samarinda Nomor18 Tahun 2013Tentang Organisasi Dan Tata Kerja Kelurahan bab III Pasal 2 Ayat 2 yaitu"Kelurahan dipimpin oleh Lurah yang berkedudukan dibawah dan bertanggung jawabkepada Kepala Daerah melalui Camat."

Salah satu kelurahan yang ada di Kota Samarinda adalah KelurahanTemindung Permai yang dibentuk berdasarkan Peraturan Daerah Kota SamarindaNomor 01 Tahun 2006 Tentang Pembentukan Kelurahan Dalam Wilayah KotaSamarinda.

\subsection{Rumusan Masalah}

Berdasarkan pengertian masalah, dapat dirumuskan permasalahan yangdiangkat dalam penelitian ini adalah: "Bagaimanakah Persepsi Pegawai NegeriSipil Terhadap Penerapan Undang-undang Nomor 5 Tahun 2014 TentangAparatur Sipil Negara di Kantor Kelurahan Temindung Permai KecamatanSungai PinangKota Samarinda." 


\subsection{Tujuan}

Tujuan penelitian ini yakni untuk mengetahui bagaimana Persepsi Pegawai Negeri Sipil TerhadapPenerapan Undang-UndangNomor5Tahun 2014 Tentang Aparatur Sipil Negara(Studi Kasus Aparatur Sipil Negara Di Kantor Kelurahan Temindung PermaiKecamatanSungaiPinangKota Samarinda), dan mengetahui dampak dari Penerapan Undang-Undang Nomor 5 Tahun2014 Tentang Aparatur Sipil Negara (Studi Kasus Aparatur Sipil Negara diKantor Kelurahan Temindung Permai Kecamatan Sungai Pinang KotaSamarinda).

\section{Teoritisasi}

\subsection{Pengertian persepsi}

Sebelum membahas definisi mengenai pegawai negeri maka peneliti terlebihdahulu mengutip beberapa pendapat para ahli tentang persepsi yaitu sebagai berikut :

Menurut Bimo Walgito (2002:87-88) "Persepsi merupakan suatu proses yang didahului oleh peoses penginderaan, yaitu proses adanya stimulus oleh individu melaluialat indera atau juga disebut proses sensorias. Namun proses itu tidak berhasil begitusajamelainkan stimulus tersebut diteruskan."

Judge Timothy dan Robbins Stephen (2008:175) yaitu "Persepsi (perception)adalah proses dimana individu mengatur dan menginterpretasikan kesan-kesansensorias mereka guna memberikan arti bagi lingkungan."

Selanjutnya menurut Rakhmat dalam Tangkilisan (2007:288) mengatakan"Persepsi merupakan pengalaman tentang objek atau peristiwa atau hubungan-hubungan yang diperoleh dengan menyimpulkan informasi dan menafsirkan pesan."

Dari penjelasan di atas dapat ditarik suatu kesamaan pendapat bahwa persepsimerupakan suatu proses yang dimulai dari penglihatan hinggaterbentuk tanggapanyang terjadi dalam diri individu sehingga individu sadarakan segala sesuatu dalamlingkungannya melalui indera-indera yangdimilikinya.

a. Syarat Terjadinya Persepsi

1) Adanya objek yang dipersepsi.

2) Adanya perhatian yang merupakan langkah pertama sebagai suatu persiapan

3) dalam mengadakan persepsi.

4) Adanya alat indera atau resptor yaitu alat menerima stimulus

5) Syarap sensoris sebagai alat untuk meneruskan stimulus ke otak yang

6) kemudian sebagai alat mengadakan respon.

b. Faktor-Faktor Mempengaruhi Persepsi

1) Faktor Fungsional

Faktor fungsional berasal dari kebutuhan,pengalaman masa lalu dan hal lainyang termasuk dalam faktor personal yang menentukan persepsi bukan jenis atau stimulus tetapi karakteristik seseorang yang memberikan respon pada stimulusitu.Adapun faktor stimulus terdiriatas :

a) Kebutuhan-kebutuhan sesaat dan kebutuhan menyerap pada diri seseorang akan mempengaruhi atau menentukan perspsi seseorang dengan demikian kebutuhan yang berbeda akan menghasilkan perbedaan persepsi.

b) Kesiapan mental,suasana mental seseorang akan mempengaruhi persepsi seseorang.

c) Suasana emosi,suasana hati seseorang baik dalam keadaan sedih, bahagia,gelisah,maupun marah akan mempengaruhi persepsi.

d) Latar belakang budaya dimana seseorang tersebut berada atau berasal akan berpengaruh terhadap suatu objek rangsangan.

2) Faktor Struktural 
Faktor struktural semata-mata berasal dari sifat stimulus fisik dan sistem syarafindividu yang meliputi: Kemapuan berfikir, Daya tangkap duniawi, Saluran dayatangkap yang ada pada manusia.

Berkaitan dengan faktor-faktor yang berperan dalam persepsi dapatdikemukakan adanya beberapa faktor, yaitu: Objek yang dipersepsi Objek yangmenimbulkan stimulus yang mengenai alat indera atau reseptor. Stimulus dapatdatang dari luar individu yang mempersepsi, tetapi juga dapat dapang dari dalamindividu yang bersangkutan yang langsung mengenai syaraf penerima yang berkerjasebagai reseptor.Namun sebagian tersebesar stimulus datang dari lluar individu.Alatindera, syaraf dan pusat susunan syaraf alat indera atau reseptor merupakan alatuntuk menerima stimulus. Di samping itu juga harus ada syaraf sensoris sebagaisyarat untuk meneruskan stimulus yang diterima reseptor ke pusat susunan syaraf,yaitu otak sebagai pusat kesadaran. Sebagai alat untuk mengadakan respondiperlukan syaraf motoris.

c. Proses Persepsi

1) Stimulus atau rangsangan terjadinya persepsi diawali ketika seseorangdihadapkan pada suatu stimulus/rangsangan yang hadir lingkungannya.

2) Registrasi dalam proses registrasi, suatu gejala yang nampak adalah mekanisme fisik yang berupa penginderaan dan syarat seseorang berpengaruh melalui alat indera yang dimilikinya. Seseorang dapat mendengarkan atau melihat informasi yang terkirim kepadanya, keimudian mendaftar semua informasi yang terkirim kepadanya tersebut.

3) Interpretasi, Interpretasi merupakan suatu aspek kognitif dari persepsi yangsangat penting yanitu proses memberikan arti kepada stimulus yang ditemanya.

4) Proses interpretasi tersebut bergantung pada cara pendalaman, motivasi, dankepribadian seseorang.

d. Pengorganisasian Persepsi

Pengorganisasian persepsi terdapat 4 (emapat) hal yang menjadi bahan persepsianatara lain :

1) Persepsi bentuk, persepsi bentuk adalah pengorganisasian bentuk-bentuk yang ada, karena dalam menginderai suatu objek manusia cenderung mempersepsi sejumlah objek secara terorganisir dalam suatu kelompok.

2) Persepsi kedalaman visual mata sebagai alat penginderaan mempunyai keistimewaan yang luar biasa, karena sebagai alat sensoris dua dimensi ia dapat melihat lingkungan secara tiga dimensi.

3) Interpretasi, Interpretasi merupakan suatu aspek kognitif dari persepsi yang sangat penting yanitu proses memberikan arti kepada stimulus yang diterimanya. Proses interpretasi tersebut bergantung pada cara pendalaman, motivasi, dan kepribadian seseorang.

4) Persepsi gerak dilihat dari gerakan suatu objek maka ada dua jenis persepsi yangdapat terjadi:

a) Real Motion, gerakan yang kita lihat dapat terjadi karena objek yang kita amatibenarbenar bergerak.

b) Apparent Motion, objek terlihat bergerak meskipun sebenarnya objek tersebut tidak bergerak.

\subsection{Pegawai Negeri}

Pegawai negeri berkedududkan sebagai unsur aparatur Negara yang bertugasmemberikan pelayanan kepada masyarakat secara professional, jujur adil dan meratadalam penyelenggaraan tugas Negara, pemerintahan danpembangunan.

Pegawai negeri menurut Undang-undang Republik Indonesia Nomor 43 Tahun 1999Tentang Pokok-Pokok Kepegawaian perubahan atas Undang-undang RepublikIndonesia Nomor 8 Tahun 1974 Tentang Pokok-Pokok Kepegawaian adalah Sebagaiberikut "Pegawai negeri adalah setiap warga Negara yang telah memenuhi syaratyang telah ditentukan, diangkat oleh pejabat yang berwenang dan diserahi tugasdalam suatu jabatan negeri,atau diserahi tugas Negara lainnya dan digaji berdasarkanperaturanperudang-undangan yang berlaku."

Pengertian Pegawai Negeri Menurut pasal 92 KUHP adalah orang-orangyang dipilih dalam pemilihan berdasarkan peraturan-peraturan umum dan jugamereka yang bukan dipilih tapi diangkat menjadi anggota DPR, DPD dan kepala-kepala Desa dan sebagainya. Pengertian 
tersebut hanya berlaku untuk kejahatanjabatan dan kejahatan-kejahatanlainnya yang diatur dalam KUHP.

Pengertian pegawai negeri menurut Undang-undang Republik IndonesiaNomor 8 Tahun 1974 Tentang Pokok-Pokok Kepegawaian bab II pasal pasal 3 yaitu"Pegawai negeri adalah unsur aparatur Negara abdi Negara, dan abdi masyarkat yangpenuh dengan kesetiaan dan ketaatan kepada pancasila, Undang-undang Dasar 1945,Negara dan pemerintah menyelenggarakan tugas pemerintahan dan pembangunan."

Menurut Undang-undang Republik Indonesia Nomor 8 Tahun 1974 TentangPokok-Pokok Kepegawaian Pasal 2 Pegawai Negeriterdiridari:

1) Pegawai Negeriterdiridari

a. Pegawai NegeriSipil; dan

b. Anggota Angkatan Bersenjata Republik Indonesia.

2) Pegawai NegeriSipil terdiridari

a. Pegawai Negeri Sipil Pusat : Pengertian Pegawai Negeri Sipil Pusat adalah PNS yang gajinya dibebankan pada anggaran pendapatan dan belanja Negara (APBN) dan bekerja pada departemen, lembaga pemerintah non-departemen, kesekretariatan Lembaga Negara, instansi vertikal di daerah provinsi, kabupaten/kota, kepaniteraan pengadilan, atau dipekerjakan untuk menyelanggarakan tugas negara lainnya.

b. Pegawai Negeri Sipil Daerah dan Pegawai Negeri Sipil lain yangditetapkan dengan Peraturan Pemerintah, Pegawai negeri sipil daerahprovinsi/kabupaten/kota yang gajinya dibebankan pada Anggaran Pendapatandan Belanja Daerah (APBD) dan bekerja pada Pemerintah Daerah ataudipekerjakan di luar instansi induknya.

\subsection{Aparatur Sipil Negara}

Aparatur sipil Negara yang dimaksud berdasarkan Undang-undangRepublik Indonesia Nomor 5 Tahun 2014 Tentang Aparatur Sipil Negara (ASN)terdapat pada babI pasal 1 ayat (2) yaitu "Pegawai aparatur sipil Negara yangselanjutnya disebut pegawai ASN adalah pegawai negeri sipil dan pegawaipemerintah dengan perjanjian kerja yang diangkat oleh Pejabat Pembinakepegawaian dan diserahi tugas dalam suatu jabatan pemerintahan atau diserahitugas Negara lainnya dan digaji berdasarkan peraturan perundang-undangan".

Selanjutnya menurut Undang-undang Republik Indonesia Nomor 5 Tahun2014 Tentang aparatur sipil Negara (ASN) terdapat pada bab I pasal 1 ayat (3) yaitu"Pegawai negeri sipil yang selanjutnya disingkat PNS adalah warga Negara Indonesiayang memenuhi syarat tertentu, dinagkat sebagai pegawai ASN secara tetap olehpejabat Pembina kepegawaian untuk menduduki jabatan pemerintahan".

Selanjutnya menurut Undang-undang Republik Indonesia Nomor 5 Tahun2014 Tentang aparatur sipil Negara (ASN) terdapat pada bab I pasal 1 ayat (4) yaitu"Pegawai pemerintah dengan perjanjian kerja yang selanjutnya disingkat PPPKadalah warga Negara Indonesia yang memenuhi syarat tertentu, yang diangkatberdasarkan perjanjian kerja untuk jangka waktu tertentu dalam rangka melaksanakantugas pemerintahan".

\subsubsection{Tugas ASN}

Tugas aparatur sipil Negara berdasarkan Undang-undang RepublikIndonesiaNomor 5 Tahun

2014 Tentang aparatur sipil Negara bab IV pasal 11 yaitu :

1) Melaksanakan kebijakan publik yang dibuat oleh pejabat Pembina kepegawaiansesuai dengan ketentuan peraturan perundang-undangan

2) Memberikan pelayanan publik yang professional dan berkualitas dan

3) Mempererat persatua dan kesatuan Negara Kesatuan Republik Indonesia.

\subsubsection{Disiplin ASN}

Berdasarkan Undang-undang Republik Indonesia Nomor 5 Tahun 2014Tentang aparatur Negara bab VIII pasal 86 Paragraf 11 yaitu :

1) Untuk menjamin terpeliharanya tata tertib dalam kelancaran pelaksanaan tugas, PNS wajib memenuhi disiplin PNS

2) Instansi pemeRepublik Indonesiantah wajib melaksanakan penegakan disiplin terhadap PNS serta melaksanakan penegakan disiplin terhadap PNS wajib terhadap PNS serta melaksanakan berbagai upaya penigkatan disiplin

3) PNS yang melakukan pelanggaran disiplin dijatuhi hukuman disiplin 
Ketentuan lebih lanjut mengenai disiplin sebagaiman dimaksud pada ayat (1),ayat (2),dan ayat (3) diatur dengan peraturan pemerintah.

\subsection{Kelurahan}

Berdasarkan Peraturan Menteri Dalam Negeri No. 31 Tahun 2006 TentangPembentukan, Penghapusan, dan Penggabungan Kelurahan, dan Permendagri28/2006 Tentang Perubahan Status Desa Menjadi Kelurahan, maka syarat-syaratpembentukan suatu Kelurahan adalah :

1) Wilayah Jawa dan Bali paling sedikit 4.500 jiwa atau $900 \mathrm{KK}$, dengan luaspaling sedikit 3 $\mathrm{km} 2$;

2) Wilayah Sumatera dan Sulawesi paling sedikit 2.000 jiwa atau $400 \mathrm{KK}$, denganluas paling sedikit $5 \mathrm{~km} 2$; dan

3) Wilayah Kalimantan, NTB, NTT, Maluku, Papua paling sedikit 900 jiwa atau180 KK, dengan luas paling sedikit $7 \mathrm{~km} 2$.

Selain itu, harus memiliki memiliki kantor pemerintahan, memiliki jaringanperhubungan yang lancar, sarana komunikasi yang memadai, dan fasilitas umumyang memadai. Kelurahan yang tidak lagi memenuhi kondisi di atas dapat dihapuskanatau digabungkan dengan kelurahan yang lain, berdasarkan hasil penelitian danpengkajian yang dilaksanakan oleh Pemerintah Daerah Kabupaten / Kota. Sedangkanpemekaran kelurahan dapat dilakukan setelah mencapai paling sedikit lima tahunpenyelenggaraan pemerintahan di kelurahan tersebut.

2.4.1. Kedudukan, Tugas, dan Fungsi Kelurahan

1) Tugas Pokok Kelurahan

Bertugas menyelenggarakan urusan pemerintahaan, pembangunan dankemasyarakatan serta urusan yang dilimpahkan oleh Walikota sesuai dengankebutuhan kelurahan dengan memperhatikan prinsip efisiensi dan peningkatanakuntabilitas.

2) Fungsi Kelurahaan

1. Melaksanakan kegiatan pemberdayaan masyarakat

2. Menyelenggarakan ketentraman dan ketertiban umum

3. Mengkoordinasikan pemeliharaan prasarana dan fasilitas umum

4. Membina lembaga kemasyarakatan

5. Membina dan mengendalikan administrasi Rukun Warga dan Rukun Tetangga

6. Melaksanakan pelayanan masyarakat yang menjadi ruang lingkup tugasnya

7. Melaksanakan tugas lain yang diberikan oleh Walikota dan/atau Camat sesuaidengan tugas dan fungsinya lurah mempunyai tugas pokok menyelenggarakanurusan pemerintahan, pembangunan dan kemasyarakatan dan melaksanakanurusan pemerintahan yang dilimpahkan oleh Walikota.

Dalam melaksanakan Tugas Pokok tersebut Lurah mempunyai Tugas yaitu :Tugas lurah

1. Pelaksanaan kegiatan pemerintahan kelurahan

2. Pemberdayaan masyarakat

3. Pelayanan masyarakat

4. Penyelenggaraan ketentrataman dan ketertiban umum

5. Pemeliharaan prasarana dan fasilitas pelayanan umum

6. Pembinaan lembaga kemasyarakatan di tingkat kelurahan.

Kelurahan dipimpin oleh seorang Lurah yang berstatus sebagai PegawaiNegeri Sipil.Kelurahan merupakan unit pemerintahan terkecil setingkat dengan desa.Berbeda dengan desa, kelurahan memiliki hak mengatur wilayahnya lebihterbatas.Dalam perkembangannya, sebuah desa dapat diubah statusnya menjadikelurahan.Kelurahan adalah wilayah kerja lurah sebagai perangkat daerah dalamwilayah kerja kecamatan lurah adalah kepala kelurahan.

2.5. Fokus Penelitian

1) Persepsi Pegawai Negeri Sipil Terhadap Penerapan Undang-Undang Aparatur Sipil Negara No.5 Tahun 2014 Tentang Aparatur Sipil Negara Di Kantor Kelurahan Temindung Permai Kecamatan Sungai Pinang Kota Samarinda. 
2) Dampak yang ditimbulkan oleh Penerapan Undang-Undang Aparatur Sipil Negara No.5 Tahun 2014 Di Kantor Kelurahan Temindung Permai Kecamatan Sungai Pinang Kota Samarinda.

\section{Metodologi}

3.1. Jenis Penelitian

Penelitian ini adalah jenis penelitian deskriptif, diaman dalam penelitiandeskriftif peneliti mengadakan penggambaran (deskripsi) mengenai situasi, kejadian,akumulasi, dan menerangkan saling berhubungan tanpa, melakuakan pengujianhipotesis.

3.2. Tekhnik pemilihan informan

Menggunakan teknik porpusive sampling atau menunjukan langsung pada sumbernya, dengan melakukan wawancara langsung,mengunakan pedoman wawancara tidak terstruktur atau pedoman wawancara yanghanya memuat garis besar yang akan ditanyakan.

3.3. Tekhnik Analisis Data

Teknik analisis data yang digunakan, yaitu metodeanalisis data deskriptif kualitatif dari Miles dan Michael Huberman, meliputi pengumpulan data, reduksi data, penyajian data, penarikan kesimpulan/verifikasi.

\section{Hasil penelitian}

4.1. Gambaran umum objek penelitian

Kota Samarinda yang merupakan Ibu Kota Provinsi Kalimantan Timur secara geografis terletak di daerah khatulistiwa pada posisi antara 0021'18"-1009'16" LS dan 116015'16"-117.24'16" BT. Di sebelah barat, timur, selatan, dan utara,daerahnya berbatasan langsung dengan kabupaten kutai kartanegara. Kota samaridadapat di capai dengan perjalanan darat, laut, dan udara. Dengan sungai Mahakamyang membelah di tengah Kota Samarinda, yang menjadi pintu menuju pedalaman Kalimantan Timur.Kota ini dengan mempunyai luas wilayah $718 \mathrm{~km} 2$ dan jumlahpenduduk 726.223 jiwa (hasil sensus penduduk Indonesia 2010).

Setelah PP No.38 Tahun 1996 terbit, wilayah Administrasi Kodya Dati II Samarindamengalami pemekaran, semula terdiri dari 4 kecamatan menadi 6 kecamatan yaitu:

1) Kecamatan Sungai Pinang : 5 Kelurahan

2) Kecamatan Samarida Ulu : 8 kelurahan

3) Kecamatan Samarinda Ilir : 5 kelurahan

4) Kecamatan Samarinda Seberang : 3 kelurahan

5) Kecamatan Sungai Kunjang : 7 kelurahan

6) Kecamatan Palaran : 5 kelurahan

Pemekaran kembali dilakukan seiring dengan pertumbuhan penduduk yang cukuppesat dan pelayanan masyarakat yang semakin meningkat. Kecamatan yangdimekarkan menjadi 10 kecamatan dan hasil pemekaran tersebut antara lain:

7. Kecamatan Samarinda Kota : 5 kelurahan

8. Kecamatan Loajanan Ilir : 5 kelurahan

9. Kecamatan sambutan : 5 kelurahan

10. Kecamatan Sungai Pinang : 5 kelurahan

Berdasarkan Peraturan Daerah kota madya daerah Tingkat II SamarindaNo.11 Tahun 1988 Tanggal 21 Januari 1988 merupakan hari jadi Kota Samarinda.dan Pesut Mahakam merupakan Maskot dari Kota Samatinda. Kota Samarinda diPimpin oleh Syaharie Jaang sebagai wali Kota Samarinda dan Nusyirwan Ismailsebagai wakil wali Kota Samarinda. Ciri - ciri penting dari penduduk kota samarindaadalah kemajemukan serta plural, baik dilihat dari pengelompokan agama, maupunadat istiadat, seni budaya dan suku. Di samping itu, ciri kependudukan kotasamarinda juga menggambarkan berbagai dinamika yang terjadi di masyarakat, baiksecara sosial maupun kultural. Menurunnya tingkat kelahiran (fertilitas) dan tingkatkematian (mortalitas), dan meningkatnya arus perpindahan antar daerah (migrasi) danterjadinya urbanisasi juga mempengaruhi kebijakan kependudukan yang diterapkan. 
Keluharan Temindung Permai merupakan salah satu dari dari kelurahanyang ada di Kecamatan Sungai Pinang dengan luas wilayah 130,56 ha dan RukunTetangga yang berjumlah 39 jumlah penduduk 17.210 jiwa dengan $4447 \mathrm{KK}$ danmempunya batas-batas wilayah sebagai berikut :

1) Sebelah Utara : Kelurahan Gungng Lingai

2) Sebelah Selatan : Kelurahan Sungai Pinang Dalam

3) Sebelah Barat : Kelurahan Bandara

4) Sebelah Timur : Kelurahan Sidodadi, Gn. Kelua dan Sempaja

5) Selatan

Rencana yang tertuang dalam bentuk Visi "Menjadikan kelurahantemindung permai sebagai pusat data,informasi dan pelayanan di bidangpemerintahan,pembangunan dan pembinaan,kemasyarakatan yang professional,mapu dan berwibawa." Dan sebagai Misinya yaitu,

1) Meningkatkan kualtas pelayanan terhadap masyarakat yangprima,transparan,akuntabel dan ringan.

2) Menigkatkan kualitas data dan informasi .

3) Mengembangkan sumber daya aparatur yang mengarah kepada professionalisme.

4) Menigkatkan peran sektor swasta dan perusahaan dalam meningkatkankesejahteraan masyarakat.

4.2. Pembahasan dan Analisa

4.2.1. Persepsi Pegawai Negeri Sipil Terhadap Penerapan Undang - Undang No. 5 Tahun 2014

Penerapan Undang-undag No.5 Tahun 2014 Tetang Aparatur Sipil Negaramerupakan penyempurnaan dari Undang-undang Pokok - pokok Kepegawaian No. 43 Tahun 1999 dimana pada undang-undang ASN yang menuntut pegawai bekerjapenuh semangat, profesional, proporsional,transparan, akuntabel, tanggung jawabserta menjunjung tinggi integritas sebagai tuntutan dari masyarkat yang sesuaiperkembangan jaman pada era globalisasi ini.

Pegawai aparatur sipil Negara harus siap melaksanakan tugas yang diberikanatasan maupun sesuai sumpahnya sebagai abdi Negara dan abdi masyarakat, di dalamundang-undang No.5 Tahun 2014 Tentang Aparatur sipil Negara bagian ke dua tugasASN pasal 11 pegawai ASN bertugas:

1) Melaksanakan kebijakan publik yang dibuat oleh pejabat Pembina kepegwaian sesuai dengan ketentuan peraturan-perundang-undangan.

2) Memberikan pelayanan public yang profesioanal dan berkualitas.

3) Mempererat persatuan dan kesatuan Negara kesatuan republik Indonesia.

Sebagai aparatur sipil Negara harus bersedia melaksanakan tugasnyaberdasarkan tugas pokok dan fungsi masing-masing, hal ini sessuai sumpahjabatannya dalam Peraruran Pemerintah No.21 Tahun 1975 Tentang Sumpah / JanjiPegawai Negeri Sipil.Didalam bekerja ASN harus dapat mempertanggungjawabakan pekerjaannya sesuai yang diberikan atasan maupun peraturan yangberlaku secara totalitas.berdasarkan pada sifat kedisiplinan Pegawai Negeri Sipiltersebut, maka dapat diartikan bahwa sikap dan tindakan Pegawai Negeri Sipil didlama dinas harus sesuai dengan sumpah dan jabatan, yaitu untuk memeliharapenghargaan dan kepercayaan masyarakat kepada korps pegawai. Denganmelalaikan tugas dan kewajiban berarti mereka harus memberikan pertanggunganjawab atas tugas yang diberikan kepadanya.

Dalam melaksanakan tugas administrasi kantor perlu adanya sarana danprasarana yang baik untu menunjang kegiatan dan tujuan yang akan dicapai. Adapunsarana dan prasarana seperti computer, mesin ketik, gedung yang layak, dan kendraandinas seperti mobil ataupun motor, akses internet, lingkungan yang bersih sehat danaman.

PNS harus memiliki kompetensi diantaranya karena tuntutan : tugas, pokok,fungsi, kewenangan dan tanggungjawab yang harus dilaksanakan, yaitu memberikanpelayanan publik pelaksanaan kepemerintahan yang baik (Good Governance) dalamupaya mengimbangi perubahan lingkungan strategis yang cepat berubah, baik itulingkungan internal organisasi, maupun lingkungan eksternal organisasiperkembangan ilmu pengetahuan, teknologi dan era globalisasi yang sedangberlangsung yang tidak bisa di tolak dan dicegah lagi serta pelaksanaan otonomidaerah.Kompetensi PNS ini berkaitan dengan kemampuan berupa pengetahuan,keterampilan, 
kecakapan, sikap dan perilaku yang diperlukan dalam pelaksanaantugas pokok, fungsi kewenangan dan tanggungjawab yang diamanatkan kepadanya.

\subsubsection{Dampak yang ditimbulkan oleh Penerapan Undang - undang No. 5 Tahun 2014 Tentang Aparatur Sipil Negara}

\subsubsection{Disiplin Pegawai}

Perubahan yang terjadi setelah diterapkannya undang-undang no.5 tahun 2014tentang aparatur sipil Negara yanang mengakibatkan disiplin pegawai berubah karenaadanya tuntutan dari yang dikehendaki oeh undang-undang dan atasannya, dimanatidak ada lagi terdapat peagawai yang tidak melakukan bolos ataupun sering keluarkantor pada saat jam kerja, dan tidak ada pegawai keluar kantor tanpa alasan jelasdan pemberitahuan juga harus jelas dengan mengisi form ( berkas ), pegawai beradadi kantor melaksanakan tugasnya masing-masing, adanya kesadaran yang tinggi daripegawai untuk melakukan kualitas disiplin yang baik.

4.2.2.2. Prestasi Pegawai

Dalam hal prestasi pegawai sejauh ini juga berjalan cukup baik.Namun belumkelihatan signifikan.

\subsubsection{Kemampuan Pegawai}

Untuk kemampuan pegawai secara umum pegawai juga berubah positifkarena kualitas pegawai yang baik dan dapat menyesuaikan dengan kebutuhan yangdibutuhkan saat ini dan tidak ada kendala dalam melakukan tugasnya.

4.2.2.4. Kewajiban dan Tanggung jawab

Kewajiban sebagai ASN abdi masyarakat dan abdi Negara sudah menjalankantugas pokok dan fungsinya masing-masing yang sesuai perintah atasan dan peraturanyang berlaku serta memberikan pelayanan yang berkualitas kepada masyarakat, danpegawai harus dapat mempertanggung jawabkan semua kerja baik kepada atasanmaupun terhadap peraturan yang berlaku, untuk sejauh ini berjalan baik dan lancardan tidak ada masalah yang sulit untuk ditangani.

\subsubsection{Produktivitas Pegawai}

Produktiivitas pegawai sejauh ini memang terjadi perubahan yang cukup baik,akan tetapi belum ada signifikan yang disebabkan ruang kerja yang cukup terbatasdan peralatan belum maksimal karena beberapa pegawai yang belum ada komputerdimejanya, yang terkena dampak dari undangundang no.5 tahun 2014 tentangaparatur sipil Negara yaitu PNS ataupun ASN dimana dampak tersebut terjadi dalammasa pensiun yang tadinya 56 menjadi 58 tahun dan golongan III menjadi pensiun60 tahun, damapaknya dirasakan bagi ASN yang tidak dapat mampu beradaptasidengan tuntutan dan tujuan dari undang-undang no.5 tahun 2014 tentang aparatursipil Negara dan reformasi birokrasi, yang akan ketinggalan dan tidak mampubersaing dan menunjukkan kualitas kerja dan prestasinya yang baik dan tidak mampubersaing dengan pegawai lainnya sesuai kebutuhan masyarakat pada era globalisasiini, tenaga honorer dimana dalam undang-undang no.5 tahun 2014 tentang aparatursipil Negara secara ekspilisi tidak ada kata honorer hanya yang ada PPPK ( PegawaiPemerintah Dengan Perjanjian Kerja ) ini merupakan wadah bagi tenaga honoreryang dipilih dan diangkat pejabat pembina kepegawaian yang disseuaikan dengankebutuhan pemerintah dan di bebankan pada APBN / APBD, masyarakat denganadanya ASN yang bekerja secara professional, proporsional dan bebas dari KKN danmemberikan kualitas pelayanan yang baik kepada masyarakat, dampak yang terjadiakibat dari penerapan undang-undang no.5 tahun 2014 tentang aparatur sipil Negarayang merasakan dampaknya jauh lebih baik dari sebelumnya, sangat jelas tujuan yangdiharapkan oleh masyarakat dan undang-undang dimana peagawai ASN diharapkanmampu bekerja secara professional, proporsional, trasnparan, kualifikasi, kompetensiserta bebas dari KKN dan bebas dari interviensi politik serta dapat memberikankualitas pelayanan yang baik kepada masyarakat.

\section{Simpulan}

5.1. Persepsi pegawai negeri sipil terhadap penerapan undang-undang no.5 tahun 2014 tentang aparatur sipil Negara di kantor kelurahan temindung permai kecamatan sungai pinang kota samarinda yaitu dengan diterapkannya undang-undang aparatur sipil Negara pegawai menyambut baik dan sangat positif dikarenakan undang-undang aparatur sipil Negara ini dapat 
meningkatkan yang lebih baik dari sebelumnya terutama pada kualitas kerja, disiplin, kemampuan, tanggung jawab yang berdasarkan prestasi dan kompetensi kinerja secara adil serta memberikan kualitas pelayanan yang baik kepada masyarakat.

5.2. Dampak yang ditimbulkan oleh Penerapan Undang-undang Aparatur Sipil Negara No. 5 Tahun 2014 Tentang Aparatur Sipil Negara Yaitu Berdampak Sangat Baik Dan Positif Dari Sebelumnya Diterapkannya Undang-Undang ASN terhadap perubahan kualitas kinerja, disiplin, produktivitas, kemampuan pegawai dan pelayanan administrasi kepada masyarakat, pegawai tidak ada lagi terdapat melakukan bolos kerja, pegawai berada pada jam kerja kantor dan tidak ada lagi keluar kantor pegawai tanpa alasan yang jelas dan pemberitahuan yang secara jelas dengan mengisi form ( berkas )

\section{Daftar Pustaka}

Undang-undang Dasar Republik Indonesia 1945,2001 (setelah Amandemen ) PT.Karya Gemilan Utama,Surabaya

Undang-UndangRepublik Indonesia No 8, 1974,dan Perubahan Undang-undang No.43,1999, Tentang Pokok-Pokok Kepegawaian. ,

Undang-undang Republik Indonesia No 5, 2014, Tentang Aparatur Sipil Negara ,

Peraturan Pemerintah No 53, 2010, Tentang Disiplin Pegawai Negeri Sipil ,

Peraturan Pemerintah Nomor 56, 2012, Tentang Pengangkatan Tenaga PNS.

Peraturan Pemerintah No 99, 2000, Dan PeraturanPemerintah No12,2002, Tentang Kenaikan Pangkat PNS

Peraturan Kepala Badan Kepegawaian Nomor 30, 2007, Tentang Pengadaan Pegawai Negeri Sipil

Peraturan Pemerintah No. 46, 2011,Tentang Penilaian Prestasi Pegawai Negeri Sipil.

Peraturan Menteri Dalam No.31, 2006, Tentang Penghapusan Dan Penggabungan Kelurahan

Peraturan Menteri Dalam Negeri No.28, 2006, Tentang Perubahan Satus Desa Menjadi Kelurahan

Peraturan Daerah Nomor 01, 2006, Tentang Pembentukan Kelurahn Dalam Wilayah Samarinda

ARIKUNTO,SUHARSIMI, 2002., Management Penelitian. Rineka Cipta, Jakarta.

AULIA HARIADDHI KHILAL, (2015), Pendekatan dalam Kualitataif, 9 Maret 2015,http://www.kompasiana.com/ilal/5-pendekatan-dalam-penelitian-

kualitatif_55300cd76ea8341e158b4581 BIMO WALGITO, 2002,Psikologi sosial, Andi offset, Yogyakarta.

DADANG SUFIANTO,2015,Pengantar Ilmu Pemerintahan, CV.Pustaka setia,Bandung

DELLY MUSTAFA, 2014,Birokrasi Pemerintahan, Alfabeta, Bandung.

HUSAINI HUSMAN danPURNOMO SETIADY AKBAR, 2008,Metodologi Penelitian Sosial, Penerbit PT. Bumi Aksara, Jakarta.

LEXY J. MOLEONG, 2000, Metodologi Penelitian Kualitatif, PT. Remaja Rodakarya, Bandung. KARTINI KARTONO, 1990,Pengantar Metodologi Research Sosial, Penerit Alumni, Bandung

MOH. PABUNDU TIKA, 2006,Metodologi Penelitian Pendidikan, Roksakarya, Jakarta.

MASRI SINGARIMBUN dan SOFYAN EFFENDI, 1995, Metode Penelitian Survey, Penerbit LP3ES, Jakarta.

MIFTAH THOHA, 2014,Manajemen kepegawaian sipil di Indonesia, Kencana, Jakarta.

NASUTION, 2003,Metodologi Research, PT. Rineka Cipta, Jakarta. 
RAHMAT SAHID, 2011,Analisis Data Model Huberman, 01 juli 2011, http://sangit26.blogspot.co.id/2011/07/analisis-data-penelitian-kualitatif.html

SUGIYONO, 2009, Metode Penelitian Kuantitatif Kualitatifdan R\&D, Penerbit CV. Alfabeta, Bandung.

SITI SHOLIHATUN MALIKAH, 2015,Analisis Data Kualitatif.17 juni 